\title{
Paideusis
}

\section{Epistemological Multilingualism: A Tool for Conviviality}

\section{Charles Scott}

Volume 18, Number 2, 2009

URI: https://id.erudit.org/iderudit/1072331ar

DOI: https://doi.org/10.7202/1072331ar

See table of contents

Publisher(s)

Canadian Philosophy of Education Society

ISSN

0838-4517 (print)

1916-0348 (digital)

Explore this journal

Cite this article

Scott, C. (2009). Epistemological Multilingualism: A Tool for Conviviality.

Paideusis, 18(2), 43-54. https://doi.org/10.7202/1072331ar

\section{Article abstract}

In a globalized world where the traditional, the modern, and the postmodern increasingly meet, there is a growing need for understanding, particularly of views different from our own. In this paper, I want to explore the concept of epistemological multilingualism and its value to scholarship, advancing the notion that epistemological multilingualism - the ability to respect and understand multiple epistemic standpoints-emerges out of a postmodern, integral perspective which sees the reality of several epistemological frameworks, as well as the ability to understand, learn from, and even to contribute to the development of those frameworks. I examine the dialogical capacities that contribute to epistemological multilingualism, and conclude that epistemological multilingualism can play a vital role in a world of education where differing worldviews manifest within the same classroom and the lives of the learners with whom we work.
This document is protected by copyright law. Use of the services of Erudit (including reproduction) is subject to its terms and conditions, which can be viewed online.

https://apropos.erudit.org/en/users/policy-on-use/ 


\title{
Epistemological Multilingualism: A Tool for Conviviality
}

\author{
CHARLES SCOTT \\ Simon Fraser University, Canada
}

\begin{abstract}
In a globalized world where the traditional, the modern, and the postmodern increasingly meet, there is a growing need for understanding, particularly of views different from our own. In this paper, I want to explore the concept of epistemological multilingualism and its value to scholarship, advancing the notion that epistemological multilingualism - the ability to respect and understand multiple epistemic standpoints-emerges out of a postmodern, integral perspective which sees the reality of several epistemological frameworks, as well as the ability to understand, learn from, and even to contribute to the development of those framenorks. I examine the dialogical capacities that contribute to epistemological multilingualism, and conclude that epistemological multilingualism can play a vital role in a world of education where differing worldviens manifest within the same classroom and the lives of the learners with whom we work.
\end{abstract}

\section{Introduction}

Subtleties matter. In a globalized world where the traditional, the modern, and the postmodern meet at coffee shops, shopping malls, college campuses, and schools, there is an increasing need for understanding, particularly of the subtleties of our lives and outlooks. Confronted with an increasing number of worldviews, there is a need for the capacity to understand those different from our own.

Might dialogue be possible, though? Might mutual understandings of various epistemic worldviews be plausible? In this paper, I want to explore what I am referring to as epistemological multilingualism and its value to scholarship and teaching. In the course of this paper, I will advance the notion that epistemological multilingualism - the ability to respect and understand multiple epistemic standpoints - emerges out of a dialogically postmodern, integral perspective which sees the reality of, and indeed the need for, several epistemological frameworks, as well as the ability to understand, to learn from, and even to contribute to the development of those frameworks. Because, as I will argue, epistemological multilingualism is fundamentally a dialogical epistemology, we can see its emergence out of stances such as those developed in relational and feminist epistemologies (see, for example, Barbara Thayer-Bacon (2003), who advocates for pluralist and fallible epistemologies). I conclude that epistemological multilingualism can play a vital role in a world of education where traditional, modern, and postmodern worlds exist within the same classroom and are manifest in the lives of the learners with whom we work. The need for us to be able not only to understand other worldviews but to work

(C) Copyright 2009. The author, Charles Scott, assigns to Paideusis the right of first publication and educational and non-profit institutions a non-exclusive license to use this document for personal use and in courses of instruction provided that the article is used in full and this copyright statement is reproduced. Any other usage is probibited without the express permission of the author. 
with and jointly develop them increases as the world changes more rapidly, and becomes more complex and closely connected. Relatedly, epistemological multilingualism allows us to more fully develop the convivial relationships-particularly I-Thou relationships-between those who might have diverse epistemic worldviews. It thus serves as what Ivan Illich (1973) refers to as a "tool for conviviality": the epistemic capacities which allow "creative intercourse among persons, and the intercourse of persons with their environment; not a conditioned response, but an active and conscious intention" (p. 11). I am suggesting that the dialogical capacities of epistemological multilingualism might help us establish the kind of "Kraftfeld" Richard Bernstein (1991) proposed in The New Constellation. If we wish to adopt relational orientations in teaching (Bingham \& Sidorkin, 2004), then we might wish to concern ourselves with means_-ways of seeing — that increase the possibilities of creative intercourse.

There are four orienting assumptions underlying this premise of epistemological multilingualism: that others are ontologically worthy in their own right, that they might possess an epistemic outlook worthy of our consideration, that we are capable of developing some degree of understanding of another's epistemic outlooks, and that we ourselves can develop an awareness of our own epistemic outlooks.

Epistemological multilingualism simply denotes an ability to consider, to attempt to understand to whatever degree possible through intentional acts, to respect, and to engage with the epistemological views or standpoints of another. It is, as Robert Solomon and Kathleen Higgins (2003, p. x) maintain, an ability to "embed ourselves in another culture, engage with another kind of life," to "see from the inside" of another's view. One's understanding is developed to a sufficient degree to enable one to "speak the language" of the other; even if one can't fully articulate the other's epistemic stance-and I will argue that the very notion of otherness requires this very recognition as a real possibility-one can at least deeply and respectfully appreciate the other as other, epistemically. Hence, paradoxically enough, epistemological multilingualism requires an admission that, despite one's best intentions and willingness, one will, possibly forever, be somewhat illiterate in the epistemic views of another. Rather than assuming the logos of mere rationality that at times reduces others to little more than logical categories (often placing them beyond normative bounds), epistemological multilingualism seeks out meanings and essence-eidos (Garrison, 2004). Whereas a rationalist unilingualism is capable of organizing and carrying out discourses, an epistemic multilingualism is also intent on listening.

Epistemological multilingualism shares characteristics with what Stuart Richmond, after Wittgenstein, refers to as resonance: "Resonance also connotes a sympathetic answering response that is in tune with, or in harmony with, the being and meaning of the other. It implies more of an emphasis on sensuous acquaintance than knowledge, something more existential, poetic and ineffable" (2007, p. 70).

\section{Articulating the Capacities of an Epistemological Multilingualism}

Several capacities contribute to epistemological multilingualism; they are an integrated matrix of intellectual, somatic, emotional, and spiritual capacities, and they can be developed through attentive work in these various domains, while at the same time one recognizes that one exists in and must pay attention to the subjective, intersubjective, and objective worlds, and to the realms of the individual and the collective (see Wilber (2001a,b) for an overview of an integral approach for the development of such capacities).

Epistemological multilingualism includes, first, an ability to articulate one's own epistemic stance and framework (an articulation that is both intellectual and existential). Second, the ability to understand and acknowledge, as fully as one is able, the epistemic views of others. This ability is necessarily dialogical, born out of one's ability to engage in dialogue with others, and can include an appreciation that your own (and others') epistemic stances have emerged out of the interactions one has (they have) had with others and with the sociocultural and ecological contexts in which one is (they 
are) submerged, just as languages are and always have been shaped by and have emerged out of interactions between interlocutors. This is, of course, a realization that epistemic positions are shaped interactively, sometimes in ways quite out of the range of our perceptions. Thayer-Bacon (2003) develops the outlines of a relational epistemology characterized by (a) the assumption that people are social creatures who interact with one another, (b) the notion that criteria for knowing are imperfect, corrigible, socially constructed, (c) a self-conscious, reflective epistemic stance that is receptive, inclusive, and adjustable, (d) an appreciation that since none of us is all-knowing we can and perhaps should reach out to develop jointly our own limited perspectives; pluralism thus helps to compensate for a (necessary) fallibilism.

The challenge of epistemological multilingualism is to bring these dialogical shapings to our awareness. There are a number of interdependent, dialogical capacities which collectively and interactively compose an overall capacity for epistemological multilingualism, and our ability to develop one capacity often depends on or results from developing the others: our capacity to listen, for example, informs and is informed by our capacity to suspend assumptions and expectations. These capacities include listening, suspending assumptions, respect and confirmation of the other, empathy and inclusion, advocacy, and an ability to stand on a "narrow ridge" of paradox. ${ }^{1}$

\section{Listening-Becoming Aware}

It seems axiomatic that one would need the capacity for listening if one is to understand another's perspective on knowledge. But like any other ability, listening is not a given: there are varying degrees of listening well, and the capacity for listening can be developed. I do not simply mean the act of physical listening with the ears, or even the processes sometimes referred to as "active listening"; rather, I mean it in the larger sense of attending to, or becoming aware of something to a greater degree. Martin Buber's (1947/2002) entire ontological conception of dialogue rests in what he calls the "basic movement" of a responsive, ontological turning toward the other which is itself made possible through the process of "becoming aware." Awareness begins its development with "meeting"-our being receptive enough to perceive that people and indeed all sentient and non-sentient beings "say something" and address us, present meaning, or reach out to contact us.

It is a different matter when in a receptive hour of my personal life a man meets me about whom there is something, which I cannot grasp in any objective way at all, that "says something" to me..... But it means, says something to me, addresses something to me, speaks something that enters my own life. (Buber, 1947/2002, p. 11)

That which is calling or addressing me may be out of my awareness and, indeed, may emerge partially from within me, but, still, in that situation, I feel addressed and so a relationship is forged. Buber adds that: "Nothing can refuse to be the vessel for the Word. ${ }^{2}$ The limits of the possibility of dialogue are the limits of awareness" (Buber, 1947/2002, p. 10). That we need to listen, to become aware, is for Buber more or less a given; however, we may not be aware of the signs of address which are present. In

\footnotetext{
1 There are several "formulations" of these dialogical capacities or "virtues," as Burbules \& Rice, (1992) characterize them (see also, for example, Bohm, 1996; Burbules, 1993; Isaacs, 1999; Yankelovich, 1999). It is not my intention to suggest that one formulation or listing is better than another. I do think, though, the variety of formulations serves to illustrate both the interconnectedness of these various capacities and the number of ways in which they can be characterized, highlighting various dialogical nuances.

2 The Word here is, of course, Logos in the sense of "word," "speech," or "reason," or in the Johannine verses of the New Testament as "Word." Gemma Fiumara (1990), Martin Heidegger (1975), and John Sallis (1986) point to the Greek sense of logos in "bringing things to lie together, collecting them, gathering them together," referring to the earlier Greek root legein. In one essence at least, logos is about creating and distilling meaning; and that it should be done together, in the Buberian "sphere of between," makes all the more sense.
} 
the postscript to $I$ and Thou (1958/2000), he writes that we often think there is nothing to hear, ". . . but long before we have ourselves put wax in our ears" (p. 126).

Signs happen to us without respite, living means being addressed, we would need only to present ourselves and to perceive. But the risk is too dangerous for us, the soundless thundering seems to threaten us with annihilation, and from generation to generation we perfect the defense apparatus.... The waves of the æther roar on always, but for most of the time we have turned off our receivers. (Buber, 1947/2002, pp. 10-11)

Listening or becoming aware is an art which can be developed; we need only "turn on" our receivers, and we do this by focusing the attention of our senses, minds, and emotions on what is before us. This is part of the dialogic "turning to the other" of which Buber speaks. The degrees of listening range from what Alphonso Lingis (1994) calls "surface-sensitivity" to "depth perception"; the latter sees surfaces but also what lies beneath the focus of the eyes, for example beneath the wrinkle of a browsees "the depth of the organism and the depth of the world" (p. 23) in personal, social, cultural, and historical codings. Another part of listening involves stilling the restlessness of the mind which prevents it from perceiving and tuning in with the "waves of the ether." Heesoon Bai outlines the means of achieving a transformative and greater awareness of the world:

What is the key to this practice? Succinctly put, it is intense, total, and sustained attention. Thus the first act we have to accomplish in learning to see is the stop. We have to stop the usual rushing-around with discursive labeling and calculative chattering.... All contemplative endeavors requiring a sustained, total, selfless attention, whether found in arts, sciences, or other endeavors, can be such [nondual-producing] technologies insofar as they yield the nonduality of the subject and the object. (Bai, 2001, p. 13)

Bai (2003) also notes that such contemplative practices allow us to listen to or meet objects as "the most foundational ontic encounter, a being-to-being encounter," where we apprehend the "suchness" of things. Artistic practices, too, have their place in developing our sensory and somatic awareness. The artistic subject or other-be it a person, an animal, a tree, or a stone-requires one's full presence and engagement, the "primary word out of [a person's] being" which allows the art to be created and to convey meaning (Buber, 1958/2000, p. 24). Buber writes that the artist's encounter is a bodily "meeting with the world" (1965, p. 151) and is propelled by the senses of receptivity and reciprocity. The artist "feels [the subject's] outlines with his limbs; a heart beats against his heart" (Buber, 1957, p. 29). In these contemplative practices there is, as Tim Lilburn (1999, p. 37) suggests, a growing familiarity, an increasing sense of feeling at home, a loving dwelling in or with a place, a river, stone, cityscape, and their inhabitants. ${ }^{3}$

Listening carefully allows us both to silence our own voices and to distinguish the "background noise of the world" (Lingis, 1994). Listening or becoming aware is perhaps the central capacity of epistemological multilingualism because it relates to our abilities to suspend assumptions, to grant respect, and to recognize otherness; listening is simply the ability to hear and hence to begin attempts at understanding another epistemic stance. Gemma Fiumara (1990, p. 19) suggests that a capacity for genuine listening "is an attitude which occupies no space but which in a paradoxical sense creates ever new spaces in the very 'place' in which it is carried out." She adds that while a singularly logocentric tradition might objectively scoff at other Weltanschaumgen, listening creates the possibility of a rigorous philosophical activity which "neither opposes the tradition of western logos nor excommunicates anything that 'normal' rationality is unable to grasp or systematize" (p. 19). Listening to that which or

${ }^{3}$ For more about the value of artistic practices in developing awareness, see, for example, Barthes, 1980; Franck, 1973; Lipsey, 2006; Lomax, 2005; London, 2003; Loori, 2004. 
those who are Other is a considerable challenge. In becoming aware, we move, however haltingly, to openness, receptivity, and other possibilities.

\section{Suspending Assumptions-Openness, Receptivity, and the Holy Insecurity}

Concomitant with listening is the willingness and capacity to remove-at least temporarily-one's assumptions about the nature of things, thus allowing more receptivity to the views of another. In a dialogical ethos, the willingness of those involved to suspend assumptions makes it more likely that joint efforts at developing and creating understanding can be undertaken by the participants; this is the pluralistic meaning making to which Thayer-Bacon refers. Suspension does not mean the abandonment of perspectives, nor does it signify the abandonment of intellectual rigor. In contrast to the rigidity of certainty, we assume both the rigors and flexibility of questioning, examination, and uncertainty. Our Western culture, however, is not a culture that often rewards uncertainty; academically, we are driven to develop knowledge that has the characteristics or at least the semblance of certainty and this makes it difficult to go against the grain. Suggesting that knowledge can be less than certain is a postmodern notion emerging out of the Nietzschean intellectual move to cast aside the "framework and planking of concepts," ontologically to "pair the most alien things," and to develop "aesthetic" relationships that are more fluid, less "correct," and quite possibly little more than "stammering translations" (Nietzsche, 1873). The "truth" now becomes a "movable host of metaphors, metonymies, and anthropomorphisms: in short, a sum of human relations which have been poetically and rhetorically intensified, transferred, and embellished ..." (Nietzsche, 1873). Meaning is now more likely to be logei, multiple, and dia, between. Suspending assumptions puts one in a position in which, as Lingis says: "With the nakedness of one's eyes... one exposes oneself to the other, with one's hands arrested in their grip on things and turned now to the other, open-handed, and with the disarmed frailty of one's voice troubled with the voice of another" (Lingis, 1994, p. 11). A dialogical epistemic possibility begins when we let down the guards of our assumptions and, as Lingis argues, we expose ourselves to another, to possible loss, sacrifice, and powers and ideas outside and foreign to ourselves.

Openness indicates a willingness to go beyond the sure boundaries of our own ideas about the way things are. The significance of this hinges on trust. Openness and a spirit of inquiry seem more possible if we feel safe, trust the unexpected, and are willing to adopt what Buber referred to as the "holy insecurity." Maurice Friedman, Buber's biographer, writes:

At the center of Buber's existentialism stands existential trust. This is the "holy insecurity" which is willing to go out to meet the unique present, rather than taking refuge in orientation and knowing one's way about. The man of "know how" wants to master the situation. The man of existential trust is able to accept the unique which is present in each new situation, despite all resemblance to the past. Real presentness means for Buber, as for [Camus'] Meursault, presence-being open to what the present brings by bringing oneself to the present, allowing the future to come as it comes, rather than attempting to turn it into a predictable replica of the past. Existential trust refuses the security of the false Either/Ors in favor of the insecurity of the "narrow ridge." (1967, p. 288)

Buber's concept of the holy insecurity arises out of his epistemic stance of devotio, the "vital knowledge" established in the "reciprocity of the essential relation to God" (Buber, 1960, p. 178), although that spirit of devotio carries over into our relations with the others and the world (which Buber did not see as separate from God). The essence of devotio is receptivity to what is reciprocally unfolding, possible, unknown - and that receptivity denotes and occurs in the presence of close, developing relationships, and it acknowledges epistemic otherness. Because it recognizes reciprocity, devotio sees knowledge as 
emergent, unfolding, unpredictable, and as developing through the relationships. ${ }^{4}$ This spirit of openness is lived in the holy insecurity of going forth into a world where there is the uncertainty of meeting, the "unforeseeable, ever changing and ever new situations" (Buber, 1963, p. 24). Buber offers little in the way of secure answers for those who read his works; the only certainty is the aforementioned uncertainty of meeting. Those who tread this path live and wrestle with that which is changing, new, and in some cases unknowable; they tread the path of what he famously calls the "narrow ridge":

I wanted by this to express that I did not rest on the broad upland of a system that includes a series of sure statements about the absolute, but on a narrow rocky ridge between the gulfs where there is no sureness of expressible knowledge but the certainty of meeting what remains undisclosed. (Buber, 1947/2002, p. 218)

The final response of Buber's philosophy of devotio and the attendant holy insecurity is that: "This very world, this very contradiction, unabridged, unmitigated, unsmoothed, unsimplified, unreduced, this world shall be-not overcome-but consummated" (Buber, 1963, p. 26). The movement is one of embracing.

Emerging out of this perspective of epistemological multilingualism would be the conjoined senses of respect for alternate epistemologies and a humble, postmodern sense that (a) one's own epistemic stance is only one in a universe of many, and (b) one's ability to know everything- that modernist totalizing tendency - is irrevocably severed. One is forced to admit one lives in a world of unknowingness.

\section{Respect-Confirmation}

It is one's awareness of and receptivity to the other which put one into relation with the other; out of that awareness and openness come the response and then the possible, attendant confirmation of the other: "... out of the incomprehensibility of what lies to hand this one person steps forth and becomes a presence" (Buber, 1947/2002, p. 25). If we are to consider another epistemic position, it stands to reason that we should be willing to grant it and its author a degree of respect. Respect for the personperson qua person-allows a foray into the respectful consideration of the person's episteme. Respect denotes the act to which the Latin roots of the word point: to look again at the other person, offering a fair consideration. Respect does not have to mean there will be agreement or consensus; respect for difference is just as (if not more) important. At its limits, respect opens up the possibility of an I-Thou relationship.

Only he who himself turns to the other human being and opens himself to him receives the world in him. Only the being whose otherness, accepted by my being, lives and faces me in the whole compression of existence, brings the radiance of eternity to me. Only when two say to one another with all that they are, "it is Thou," is the indwelling of the Present Being between them. (Buber, 1947/2002, p. 35)

Respecting the other person allows us to "confirm" the other, as Buber (1965) puts it. Even though we might strongly disagree with the other, Buber feels it essential that we hold the other with respect,

\footnotetext{
${ }_{4}^{4}$ Devotio represents a phenomenological perspective in which the knowledge of a thing is contained in the relationship itself; thus a thing cannot be spoken of something in and of itself since it is ontically defined in and through the relationship it has with something or someone else. This is why Buber refused to see God as anything but a dynamic, unfolding presence whose nature is made manifest by the relationships between God and people. This is also why Buber could consider a dialogical relationship with an animal, a tree, or even a stone. The classic Buberian reference is his consideration of a tree in $I$ and Thou.
} 
confirming the other's presence and intrinsic value as a vehicle of Present Being; we are "making present" the other as other; we are validating and indeed glorifying what Buber called Urdistanz, ontological separation and otherness. In his essay "Distance and Relation," he writes that those who turn to the world and become aware of it "step into relation with it." What is significant, though, is that this is an integrated, holistic knowing:

$\ldots$ he $\ldots$ becomes aware of wholeness and unity in such a way that from then on he is able to grasp being as a wholeness and a unity; the single being has received the character of wholeness and the unity which are perceived in it from the wholeness and unity perceived in the world. (Buber, 1965, p. 63)

At the same time, however, ontological individuality remains. To fully comprehend unity, one has to also have an appreciation of ontological individuality. As Buber continues: "This making present increases until it is a paradox in the soul when $\mathrm{I}$ and the other are embraced by a common living situation ..." (p. 70). What is significant as well is that the epistemic stance of devotio and the resultant awareness and turning to confirm the other are brought on by a conscious act of will; Buber here refers to entering into relation as an act and as work.

Lingis (1994) goes so far as to say that we are "burdened" with the sentiment of respect. An epistemological multilingualism born of respect, of confirmation of the other, helps us avoid the modernist tendencies towards what Zygmunt Bauman (1993) calls assimilation, in which we "devour" and "transform" strangers into creatures indistinguishable from ourselves, or marginalization, the "banishing " or "vomiting" of strangers. We thus avoid the totalizing tendencies of modernism (Bauman, 1993; Biesta, 2004), along with the tendency to "look down" on other perspectives, perhaps offering token appreciation (Solomon \& Higgins, 2003). Confirmation allows for co-existence in the midst of difference.

Giving due consideration to the episteme of another is to offer that stance a status equal to one's own or considering it worthy of careful consideration. Relatedly, it means treating the other person as an ontological equal — which can be challenging because so often we understandably define others by their relative social roles. But while we should be willing to at least temporarily hold others as ontological and epistemic equals, this does not mean we are the same; equality often does not exist. Others remain others (other qua other), worthy of respect as others, different from us. Honoring otherness is challenging. Seeing the other as (absolutely) Other offers a respectful, humble, ethical stance, one of distance. Can there be understanding in the face of a lack of access or a sense of unity? I believe there can be, although I would stress, as I did above, that our knowing will be limited and fallible, and that the other remains other.

To be sure, the other presents a challenge. There is what Lingis (1994) refers to as the "intruder," or the "stranger," the one with whom we, representing the rational community, have "nothing in common." This community of others "troubles the rational community, as its double or its shadow" (p. 10). Thus recognition of the Other and the epistemology of the Other can serve as a means of seeing the shadow side of ourselves (and, perhaps, the shadow side of rationality itself; moreover, postmodernity has its own shadows). But the other represents an imperative which contests commonality. Those of us in the rational community tend to legitimate rationalist epistemic stances, marginalizing other ways of being in and seeing the world.

\section{Empathy-Inclusion}

We come then to empathy, the ability to identify with the other as closely as possible, to walk in others' shoes, to see through their eyes, hear through their ears, think their thoughts, and feel their feelings. Again, one's ability to do so is an outcome of our ability to become more fully aware of the other-and being aware that as other, the other remains somewhat beyond our empathic efforts. Abram (1996, p. 
ix) suggests we are predisposed to a sense of empathy: all our senses engage us with the world, we have developed language which allows us to communicate and understand, and we seem to have an almost instinctual need to be in relationships.

Thomas Merton (1998, pp. 206-207) outlines the bounds of empathy or inclusion. He notes it as a part of a "transcultural maturity" he calls "final integration." Such individuals apprehend their lives "fully and wholly from an inner ground that is at once more universal than the empirical ego," and yet that inner ground remains unique to each individual. There is a "cosmic" or "universal" identification with others: being able to "experience their joys and sufferings" without becoming overwhelmed by them. These persons experience the wide array of human experience, at the same time passing beyond any limiting forms, keeping what is universal. Buber writes, in $I$ and Thou:

In the eyes of him who takes his stand in love, and gazes out of it, men are cut free from their entanglement in bustling activity. Good people and evil, wise and foolish, beautiful and ugly, become successively real to him; that is, set free they step forth in their singleness, and confront him as Thou. In a wonderful way, from time to time exclusiveness arises-and so he can be effective, helping, healing, educating, raising up, saving. Love is responsibility of an $I$ for a Thou. (Buber, 1958/2000, p.29)

Empathy offers the possibility to form a sympathetic bond with the epistemological outlook of another, without necessarily having to agree with it. Empathy affords us more opportunity to offer a dispassionate appraisal. ${ }^{5}$

\section{Advocacy: Modernist and Postmodernist}

As a strong representative of modernity, Jürgen Habermas (1979) states that the goal is "intersubjective mutuality of reciprocal understanding, shared knowledge, mutual trust, and accord with one another " (p. 3). Each participant has a moral obligation to meet the "universal validity claims" of truth (speaking something that can objectively be determined as being true), truthfulness (having an intention of being truthful), and rightness (being mindful of existing social and cultural norms and values). Apart from this modernist metaprescriptive stance, we have the postmodern paralogy of Jean-François Lyotard (1984), which petitions players to accept different norms (p. 65). Lyotard abandons modernity's absolute claims, concluding that: “ ... it seems neither possible, nor even prudent, to follow Habermas in orienting our treatment of the problem of legitimation in the direction of a search for universal consensus through what he calls Diskurs, in other words, a dialogue of argumentation” (p. 65). Paralogy is for Lyotard, after Wittgenstein, a plurality of language games that does not seek any "regularization of the moves" in conversation, where the noble ideal of justice need not lie in consensus. But Lyotard does not abandon civility or ethics and he adds that consensus need not be abandoned completely;

\footnotetext{
${ }^{5}$ It is worth noting that in his essay on education, Buber raises a concern with empathy, noting that it means "to glide with one's own feeling into the dynamic structure of an object ... or even of an animal or a man," or "to 'transpose' oneself over there and in there. Thus it means the exclusion of one's own concreteness ... (1947/2002, p. 115). He argues instead for "inclusion," which he defines as "the complete realization of the submissive person, the desired person, the 'partner,' not by the fancy but by the actuality of the being" (p. 114). The significant difference for him between empathy and inclusion is that the latter is the "extension of one's own concreteness, the fulfillment of the actual situation of life, the complete presence of the reality in which one participates" (p. 115). I would simply argue that what most people today consider as empathy is synonymous with inclusion; I certainly feel the two are synonymous - that empathy does not mean any degree of exclusion of one's own existential presence. Buber (1947/2002) argues that one of the salient features of inclusion is that an individual, "without forfeiting anything of the felt reality of his activity, at the same time lives through the common event from the standpoint of the other" (p. 115); I think it is reasonable to suggest that empathy must have this quality, hence my use of the term empathy alongside "inclusion."
} 
rather, the rules and moves would be determined locally, by the participants, and ever be subject to review by them.

Buber strongly advocates advocacy as a demonstration of presence; his entire dialogical philosophy of the I-Thou relationship is founded on the recognition of the ontological validity of otherness and the full presence of the $I$. In his response to Søren Kierkegaard on the nature and roles of the "Single One," Buber repeatedly urges a strong voice as a manifestation of a dialogical ontology; one is to "give the answer from the depths, where a breath of what has been breathed in still hovers-and let no one prompt you" (1947/2002, p. 77); the existential person who "stakes his life in his thinking" is to bring this thought into her or his relations, and the dialogical responsibility is just that: to respond. Lingis (1994, p. 32) writes of the "alien imperative" which calls for response from us. We are not merely meant to listen, but to respond; responsiveness is found in both. Communication lies in listening and response, seeking to clarify, questioning, and developing understanding, and seeking to separate meaning from extraneous noise, whether internal or in the background-and all this with a concern for the welfare of the other. Epistemological multilingualism allows and even requires that one be willing to enter into the development of worldviews. Buber and Lingis agree that the Other or the community of others commands you to speak, and with your own unique voice-a voice that might be incomprehensible to the ear of the modernist.

In the presence of the postmodern ethos of otherness that Lingis and others outline, is there any place for the skills and requirements of communicative action delineated by Jürgen Habermas (1979, 1991), and can they play a part in developing an epistemological multilingualism? I would suggest that paralogy does not abandon all of the norms of Habermas' communicative action or the possibility of consensus as part of an engagement between two camps. I am aware that some forms of a postmodern ethos actively reject the Habermasian calls for mutual, rational understanding and agreement. Lingis (1994) notes that the person whose life values veracity and responsibility "opens each of its austerelywon convictions to every contestation to come" and "sees every response made as a settlement not responsible enough, that has to be subjected to further demands" (p. 60). This sounds like a willingness to engage with the modernist and postmodernist. I would suggest, similarly to Richard Bernstein (1995) and Ken Wilber (20001a,b), that a truly dialogical ethos of responsiveness can transcend and yet include the epistemic stances of modernism and postmodernism. Bernstein agrees with Thayer-Bacon's (2003) call for an "engaged fallibilistic pluralism." His new constellation of the engagements of modernity and postmodernity does not seek a position of final reconciliation, but rather a Kraftweld (forcefield) of dynamism: "a relational interplay of attractions and aversions that constitute the dynamic transmutational structure of a complex phenomenon," where we "learn to think and act in the inbetween' interstices of forced reconciliations and radical dispersion" (1995, p. 9).

The possibility—and likely the probability—of significant tension or even conflict in classrooms remains, as the essays in Megan Boler's (2004) edited collection, aptly titled Democratic Dialogue in Education: Troubling Speech, Disturbing Silence, make clear. These tensions and conflicts are not only possibly inevitable but are, as William Isaacs (1999) argues, an inevitable and essential part of the dialogue process. ${ }^{6}$ We may need to recognize that conflict is likely and be able to engage in it while preserving respect for others and their views: maintaining I-Thou relationships in the midst of dialogical inquiries which can "heat up."

\footnotetext{
${ }^{6}$ Isaacs notes four stages to the dialogue process: first, initial explorations where participants try to sense out each other without giving rise to conflict; second, a conflictual stage where the differing assumptions and worldviews come to the fore; third, upon realizing that they have to suspend their assumptions and adopt degrees of receptivity, the participants embark upon creative forms of inquiry, jointly considering alternatives and possibilities; fourth, an emergent sense of collective thought and identity, coupled with a mindful overarching awareness of the entire process (metalogue).
} 


\section{The Narrow Ridge of Paradox and Nondualism}

Considering listening, suspension and advocacy, empathy and otherness, not to mention the tensions of modern and postmodern forms of advocacy, has us balancing, dynamically, on the narrow ridge where, as Buber (1963, p. 17) puts it, "the unity of the contraries" exists; it is, he asserts, the "mystery at the innermost core of the dialogue." On the one hand, Buber asserts that the dialogical person can know the other in "all his otherness" and can break through to the other (1947/2002, p. 239)—but otherness remains. "On the far side of the subjective, on this side of the objective, on the narrow ridge, where $I$ and Thou meet, there is the realm of 'between"' (p. 243). Echoing Buber, Gert Biesta (2004) points out that a postmodern response does not operate within a dualistic framework of either-or, but transcends relativism and universalism, subjectivism and objectivism. Biesta goes on to point out that a postmodern epistemic perspective recognizes and avoids the totalizing, all-encompassing tendencies of modernist or traditional epistemic worldviews, offering respect to more than one epistemic possibility. Buber's "narrow, rocky ridge" rests between. That sphere of between may represent a manifestation of the Krafteld Bernstein envisions. It may be difficult if not impossible fully to enact epistemological multilingualism without the capacity to rest comfortably with paradox and without an ability to transcend seemingly irresolvable dualities.

\section{Educational Implications}

If education involves (among other things) the development of a sense of self, then epistemological multilingualism facilitates that making of a self formed in relation to others. As Thayer-Bacon (2006) puts it, "A transactional view of individuals-in-relation-to-others helps us underscore the importance of sharing identities in democracies that are always-in-the-making" (p. 89). Epistemological multilingualism offers us the chance to free ourselves from what Charles Taylor (1991b) calls the "iron cages" of atomistic, reductionist, and instrumental worldviews, and to form a more responsive, "dialogical self" (1991a) constructed with and from the interactions and contexts of others with whom we interact. It is a self that is less defined by certitude and more by openness and receptivity. The dynamics of teaching shift; rather than a one-way epistemic relationship flowing from "teacher" to "student," we now have a more dialogical, multi-directional epistemic flow between learners. Holding others as epistemic partners has particular significance for us in both education and academia: what forms of knowledge and whose knowledge are we willing to privilege with authority, validity, and reliability?

Bai (2006) centers human agency in a sense of self that is not atomistic, but rather finds expression in the cultivation of a "humane sensibility" in the "communal effort at person-making" (p. 15). The practice of democracy rests, Bai asserts, on a foundation of intersubjectivity. It is a foundation that is, as Thayer-Bacon (2006) similarly contends, a "transactional" and "relational" system.7 Epistemological multilingualism as a philosophical practice of education increases the likelihood of developing a sense of self that is subjectively and intersubjectively integrated and harmonized within and without. More significantly, it is a self which can meaningfully relate to others and a sociocultural milieu which is increasingly complex, pluralistic, and more rapidly changing, and is less likely to reject out of hand otherness in personhood or knowledge.

Buber(1947/2002) notes in his essay "What is Man?" that dialogue is

\footnotetext{
${ }^{7}$ It is worth noting that Thayer-Bacon, like Buber before her, rejects the either-ors of both individualism and communitarianism. She argues for a "both/and logical approach," while Buber's "genuine third alternative" (1947/2002, p. 240ff) was the sphere of between which could not be reduced to either pole and transcended a compromise.
} 
rooted in one being turning to another as another, as this particular other being, in order to communicate with it in a sphere which is common to them but which reaches out beyond the special sphere of each. I call this sphere, which is established with the existence of man as man but which is conceptually still uncomprehended, the sphere of "between." ... This is where a genuine third alternative must begin. (p. 241)

I suggest that the dialogical moves to this Buberian sphere of between represent the kind of efforts that can make the Kraffeld Bernstein envisioned more of a possibility, one where learners representing traditionalism, modernity, and postmodernity can fruitfully engage. A key focus in developing epistemological multilingualism is practice; the capacities mentioned above can be developed through practice, and curricula and pedagogy both can offer opportunities for practice. But it is clear that the dialogical engagements which can emerge out of epistemological multilingualism can be challenging and difficult, requiring considerable prudence, courage, and care. Out of such a sense of relational autonomy a richer democracy, one that is relational, contingent, and pluralistic, can emerge.

\section{Acknowledgements}

The author would like to thank Peter Kovacs, Heesoon Bai, and Sean Blenkinsop for feedback on earlier drafts of this work. The author also deeply appreciates the perceptive suggestions and convictions of the reviewers. The limitations of the paper remain wholly my own.

\section{References}

Abram, D. (1996). The spell of the sensuous. New York: Vintage Books.

Bai, H. (2001). Challenge for education: Learning to value the world intrinsically. Encounter, 14(1) 4-16.

Bai, H. (April 2003). The stop: The practice of reanimating the universe within and without. Educational Insights, 8(1). Retrieved Dec. 1, 2007 from http://www.csci.educ.ubc.ca/publication/ insights/v08n01/contextualexplorations/bai/bai.html

Bai, H. (2006). Philosophy for education: Towards human agency. Paideusis, 15(1), 7-19.

Barthes, R. (1980). Camera lucida. New York: Hill and Wang.

Bauman, Z. (1993). Postmodern ethics. Oxford: Blackwell Publishing.

Bernstein, R. (1991). The new constellation: Ethical-political horizons of modernity/postmodernity. Cambridge, MA: MIT Press.

Biesta, G. (2004). The community of those who have nothing in common: Education and the language of responsibility. Interchange,35(3), 307-324.

Bingham, C. \& Sidorkin, A. (2004). (Eds.). No education without relation. New York: Peter Lang.

Bohm, D. (1996). On dialogue. London: Routledge.

Boler, M. (Ed.) (2004). Democratic dialogue in education: Troubling speech, disturbing silence. New York: Peter Lang.

Buber, M. (1947/2002). Between man and man. (R. Smith, Trans.). London: Routledge.

Buber, M. (1963). Israel and the world: Essays in a time of crisis (2nd ed.). New York: Schocken Books.

Buber, M. (1957). Pointing the way: Collected essays. New York: Books for Libraries Press.

Buber, M. (1958/2000). I and thou. (R. Smith, Trans.). New York: Scribner.

Buber, M. (1960). The origin and meaning of Hasidism (M. Friedman, Trans.). New York: Horizon Press.

Buber, M. (1965). The knowledge of man: Selected essays (R. Smith \& M. Friedman, Trans.). New York: Harper Row.

Burbules, N. (1993). Dialogue in teaching: Theory and practice. New York: Teachers College Press. 
Burbules, N. \& Rice, S. (1992). Communicative virtues and educational relations. Philosophy of Education Yearbook. Retrieved October 24, 2007 from http://www.ed.uiuc.edu/EPS/PESYearbook/92 docs/rice burbules.HTM

Fiumara, G. (1990). The other side of language: A philosophy of listening. London: Routledge.

Franck, F. (1973). The Zen of seeing: Seeing and drawing as meditation. New York: Vintage Books.

Friedman, M. (1967). To deny our nothingness: Contemporary images of man. N.Y.: Dell Publishing.

Garrison, J. (2004). Ameliorating violence in dialogues across differences: The role of eros and lógos. In Boler, M. (Ed.) (2004). Democratic dialogue in education: Troubling speech, disturbing silence (pp. 89-104). New York: Peter Lang.

Habermas, J. (1979). Communication and the evolution of society. Boston: Beacon Press.

Habermas, J. (1991). Moral consciousness and communicative action. Cambridge, MA: MIT Press.

Heidegger, M. (1975). Early Greek thinking (D. Krell \& F. Capuzzi, Trans.). New York: Harper \& Row.

Illich, I. (1973). Tools for Conviviality. New York: Harper \& Row.

Isaacs, W. (1999). Dialogue and the art of thinking together. New York: Currency Books.

Lillburn, T. (1999). Living in the world as if it were home. Toronto: Cormorant Books.

Lingis, A. (1994). The community of those who have nothing in common. Bloomington, IN: Indiana University Press.

Lipsey, R. (2006). Angelic mistakes: The art of Thomas Merton. Boston: Shambhala.

Lomax, Y. (2005). Sounding the event: Escapades in dialogue and matters of art, nature and time. London: I.B. Tauris.

London, P. (2003). Drawing closer to nature: Making art in dialogue with the natural world. Boston: Shambhala.

Loori, J. (2004). The Zen of creativity: Cultivating your artistic life. New York: Ballantine Books.

Lyotard, J.-F. (1984). The postmodern condition: A report on knowledge (G. Bennington \& F. Jameson, Trans). Minneapolis, MN: University of Minnesota Press.

Merton, T. (1998). Contemplation in a world of action. Notre Dame, IN: Notre Dame University Press.

Nietzsche, F. (1873). On truth and lies in a nonmoral sense. Unpublished document. Retrieved July 12, 2007 from http://www.answers.com/topic/on-truth-and-lies-in-a-nonmoral-sense

Richmond, S. (2007). Resonance and the photographing of medieval architecture. Paideusis, 16(3), pp. 69-82.

Sallis, J. (1986). Being and logos: The way of Platonic dialogue. Atlantic Highlands, NJ: Humanities Press International.

Solomon, R. \& Higgins, K.).(2003). Introduction. In R. Solomon \& K. Higgins (Eds.), From Africa to Zen: An introduction to world philosophy (2nd ed.) (pp. ix-xvi). Lanham, MD: Rowman \& Littlefield.

Taylor, C. (1991a). The dialogical self. In D. Hiley (Ed.), The interpretive turn: Philosophy, science, culture (pp. 304-314). Ithaca, NY: Cornell University Press.

Taylor, C. (1991b). The malaise of modernity. Toronto: House of Anasai Press.

Thayer-Bacon, B. (2003). Relational (e)pistemologies. New York: Peter Lang Publishers.

Thayer-Bacon, B. (2006). Beyond liberal democracy: Diverse educational relations. Paideusis, 15(2), 79 91.

Wilber, K. (2001a). A brief history of everything. Boston: Shambhala.

Wilber, K. (2001b). Sex, ecology, and spirituality. (2nd Rev. ed.) Boston: Shambhala.

Yankelovich, D. (1999). The magic of dialogue. New York: Simon \& Schuster.

\section{About the author}

Charles Scott is a doctoral candidate in the Faculty of Education at Simon Fraser University. His research interests include the applications of dialogue in educational settings and relational pedagogies, the roles of contemplative arts in education, and the teaching of academic writing. 